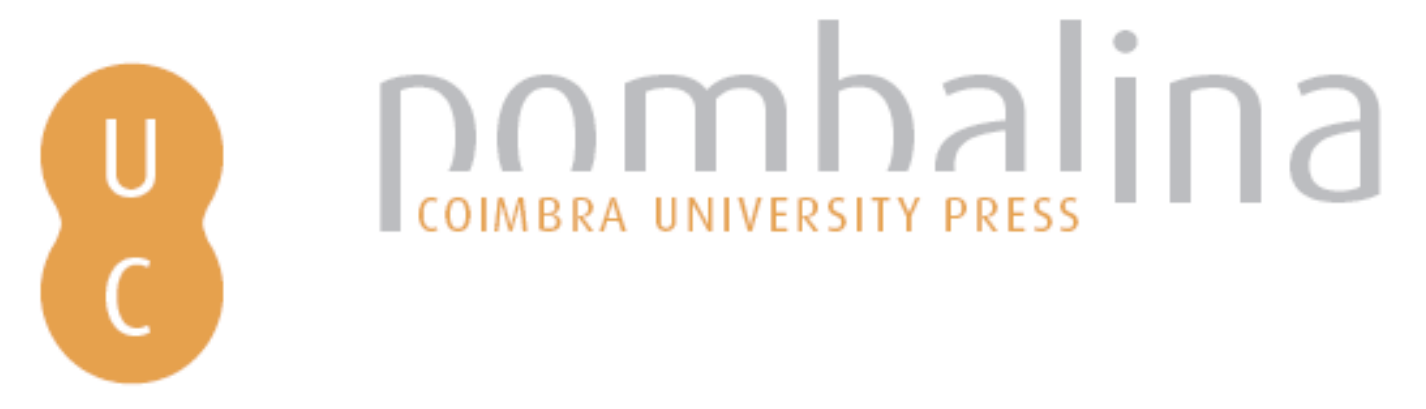

\title{
Study of growth of free-burning grass fires from point ignition
}

Autor(es): $\quad$ Sullivan, A. L.; Cruz, M. G.; Hilton, J. E.; Plucinski, M. P.; Hurley, R.

Publicado por: Imprensa da Universidade de Coimbra

URL

persistente: URI:http://hdl.handle.net/10316.2/44588

DOI: $\quad$ DOI:https://doi.org/10.14195/978-989-26-16-506_71

Accessed : $\quad$ 26-Apr-2023 08:41:27

A navegação consulta e descarregamento dos títulos inseridos nas Bibliotecas Digitais UC Digitalis, UC Pombalina e UC Impactum, pressupõem a aceitação plena e sem reservas dos Termos e Condições de Uso destas Bibliotecas Digitais, disponíveis em https://digitalis.uc.pt/pt-pt/termos.

Conforme exposto nos referidos Termos e Condições de Uso, o descarregamento de títulos de acesso restrito requer uma licença válida de autorização devendo o utilizador aceder ao(s) documento(s) a partir de um endereço de IP da instituição detentora da supramencionada licença.

Ao utilizador é apenas permitido o descarregamento para uso pessoal, pelo que o emprego do(s) título(s) descarregado(s) para outro fim, designadamente comercial, carece de autorização do respetivo autor ou editor da obra.

Na medida em que todas as obras da UC Digitalis se encontram protegidas pelo Código do Direito de Autor e Direitos Conexos e demais legislação aplicável, toda a cópia, parcial ou total, deste documento, nos casos em que é legalmente admitida, deverá conter ou fazer-se acompanhar por este aviso.

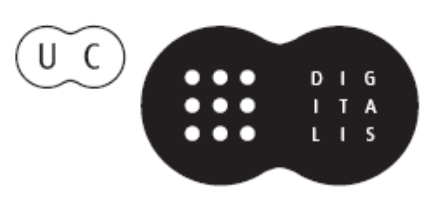




\section{ADVANCES IN}

\section{FOREST FIRE RESEARCH}

\section{8}

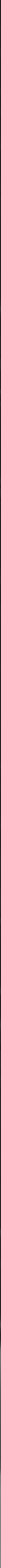




\title{
Study of growth of free-burning grass fires from point ignition
}

\author{
A.L. Sullivan ${ }^{1 *}$; M.G. Cruz ${ }^{1}$; J.E. Hilton ${ }^{2}$; M.P. Plucinski ${ }^{1}$; R. Hurley ${ }^{1}$ \\ ${ }^{1}$ CSIRO GPO Box 1700 Canberra, ACT, Australia \{Andrew.Sullivan@csiro.au*\} \\ ${ }^{2}$ CSIRO/Data61, Private Bag 10, Clayton South, Victoria, Australia
}

\begin{abstract}
Understanding wildland fire behaviour between ignition and attainment of the 'steady state' rate of spread is important for determining the speed of development of the fire and the accurate identification of the window of maximum effective first attack. As part of a larger experiment studying the behaviour of free-burning experimental grassland fires conducted in the open, the opportunity was taken to gather data on the development, behaviour and spread of fires ignited at a point, as would generally occur in a wildfire. These experimental fires, carried out in fully cured open improved pasture approximately $10 \mathrm{~km} \mathrm{NW}$ of Braidwood, NSW, Australia, were conducted on $0.1-0.2$ hectare plots and provided the most detailed insights into the behaviour of nascent fires burning in the open conducted in Australia since the work of McArthur (1966) and Cheney et al (1993).

This talk provides a general overview of this subset of experiments and the methods used to collect high spatial resolution data about the growth and development of free-burning point ignition fires in the open. As most fires in this series were very short-lived and were open to the vagaries of the prevailing wind field, traditional methods of measuring and documenting fire behaviour and spread were not practical-fires generally lasted less than two minutes. As a result, video footage taken from a quad-copter unmanned aerial vehicle (or remotely piloted aircraft or drone) hovering above the fire was used to map the progression of each fire. Details of the method by which footage is rectified and corrected, scaled and digitized will be provided as will a summary of the results obtained thus far.
\end{abstract}

Keywords: Fire behaviour, fire growth, acceleration, field experiments, wildfire, analysis, drone, remotely piloted aircraft

\section{Introduction}

Knowing precisely how long it will take a wildland fire to attain its 'steady state' rate of spread for the prevailing conditions after it breaks out is important for determining the window of opportunity when first attack or suppression will be most effective. Similarly, detailed information about the growth of an outbreak will assist with high fidelity prediction of the overall shape and extent of the fire. The behaviour of the fire during this period is generally described as the fire growth or acceleration phase (Luke and McArthur 1978, McAlpine and Wakimoto 1991). Most wildfires occur as point ignitions (e.g. from lightning, accidental causes or malicious causes). Similarly spotfires also start from points. Therefore understanding the processes involved in the transition from a point ignition to a fully developed going fire will provide insight into two very important aspects of wildland fire management (Sullivan et al. 2013).

The factors that may affect a fire's acceleration include the magnitude and variability of the speed and direction of the wind, the openness of the fuels to the wind, the moisture content, structure, availability and spatial distribution of the fuel, and local topography. A fire that has very rapid acceleration will complete its growth phase relatively quickly and achieve a behaviour and propagation rate commensurate with the prevailing conditions. A fire that has a very slow acceleration will take time to develop the flame structure and heat transfer rates associated with steady-state behaviour and thus may be more amenable to direct suppression and more readily controlled. Determining how long a fire will take to complete its acceleration phase will help enable suppression resources to respond 
most effectively to that fire - is direct attack likely to be effective when crews arrive or should they immediately implement indirect suppression tactics?

As part of a larger experiment studying the behaviour of free-burning experimental grassland fires conducted in the open, the opportunity was taken to gather data on the development, behaviour and spread of fires ignited as points for the purpose of building a dataset to enable development of an operational model of fire acceleration.

\section{Method}

\subsection{Experimental design}

The experimental fires, carried out in fully cured open improved pasture approximately $10 \mathrm{~km} \mathrm{NW}$ of Braidwood, NSW, were conducted on $0.1-0.2$ hectare plots. Plots of this size were deemed large enough to enable fire growth to be unconstrained and representative of naturally occurring fires, yet small enough to enable replication and ease of control. A preliminary analysis of seven of these fires is presented here.

Wind speed and direction was measured at $2 \mathrm{~m}$ (at two locations $<50 \mathrm{~m}$ up wind of the ignition locations) and $10 \mathrm{~m}$ above ground level (at one location within $300 \mathrm{~m}$ of each fire) at $10 \mathrm{~Hz}$. Air temperature and relative humidity were measured at $1.2 \mathrm{~m}$ at the $10 \mathrm{~m}$ measurement site at the same rate.

The experimental fires were ignited using a single match dropped at a time and location determined by the local wind gust structure and direction to maximise the potential for the fire to burn across the full length of the block with the fire allowed to burn out the entire plot. As soon as any part of the fire perimeter reached a plot boundary the experiment was considered over. Fire progression and flame characteristics were noted by a ground observer in close proximity to the fire as it developed until the fire front reached a plot boundary.

Prior to ignition a DJI Phantom 4 remotely piloted aircraft (RPA) mounted with a DJI high definition video camera was launched and positioned at an altitude and location such that its camera had as planar view of the plot as possible but which allowed for potential occlusion of the view of the head fire by smoke.

\subsection{Fire perimeter mapping and rate of spread measurement}

RPA footage was initially trimmed to the period covering fire ignition and experiment completion. The footage was then corrected for image distortion (i.e. spatially rectified to present as planar an image as was possible within the limits of the original footage, scaled and clipped to the extents of the experimental plot). This was done using purpose-built software written in the CSIRO Workspace environment (Cleary et al 2015) that utilises the OpenCV2 video analysis editing library (Bradski 2000) and the corners of the plots as control points. The fire perimeter was manually digitised using WebPlotDigitiser v3.8 ${ }^{1}$ from selected scaled images at 5 to 10 second intervals depending on fire speed. This enabled expert assessment of fire edge location which may be occluded by tall flame or smoke at a resolution of 3 and $8 \mathrm{~cm}$.

Fire behaviour metrics such as area, perimeter length, as well as rate of change in these quantities, were calculated directly from these data using an $\mathrm{R}$ script as was a fire isochrone map in which fire

${ }^{1}$ http://arohatgi.info/WebPlotDigitizer 
perimeters at each time interval were plotted. From each isochrone in the isochrones map additional fire behaviour metrics such as cumulative and interval distance and angle travelled, fire shape (length and breadth) and orientation, and headfire width (see Cheney and Gould 1995) were measured for each time step using the image analysis and processing software Image ${ }^{1}$. From these metrics, fire length to breadth ratio, cumulative and interval rate of spread, were calculated.

\section{Results}

Table 1 summarises the burning conditions of these fire experiments.

Table 1 - Summary of range of conditions for experimental point ignition fires.

\begin{tabular}{|c|c|c|c|c|c|c|c|c|}
\hline $\begin{array}{l}\text { Time of } \\
\text { day } \\
\text { (hh:mm) }\end{array}$ & $\begin{array}{l}\text { Air } \\
\text { temperature } \\
\left({ }^{\circ} \mathrm{C}\right)\end{array}$ & $\begin{array}{l}\text { Relative } \\
\text { Humidity } \\
(\%)\end{array}$ & 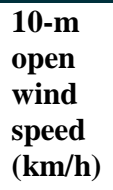 & $\begin{array}{l}\text { Curing } \\
\text { level } \\
(\%)\end{array}$ & $\begin{array}{l}\text { Overall } \\
\text { fuel } \\
\text { moisture } \\
\text { content } \\
(\%)\end{array}$ & $\begin{array}{l}\text { Duration } \\
\text { (s) }\end{array}$ & $\begin{array}{l}\text { Maximum } \\
\text { cumulative } \\
\text { rate of fire } \\
\text { spread }(\mathrm{m} / \mathrm{min})\end{array}$ & $\begin{array}{l}\text { Maximum } \\
\text { interval rate of } \\
\text { fire spread } \\
(\mathrm{m} / \mathrm{min})\end{array}$ \\
\hline $\begin{array}{ll}11: 02 & - \\
16: 24 & \end{array}$ & $24-29$ & $21-30$ & $\begin{array}{l}14.8- \\
32.1\end{array}$ & $80-100$ & $5.9-12.9$ & $50-110$ & $15.4-66.9$ & $29.9-145.4$ \\
\hline
\end{tabular}

Figure illustrates the result of the image correction, rectification and cropping of raw RPA imagery.
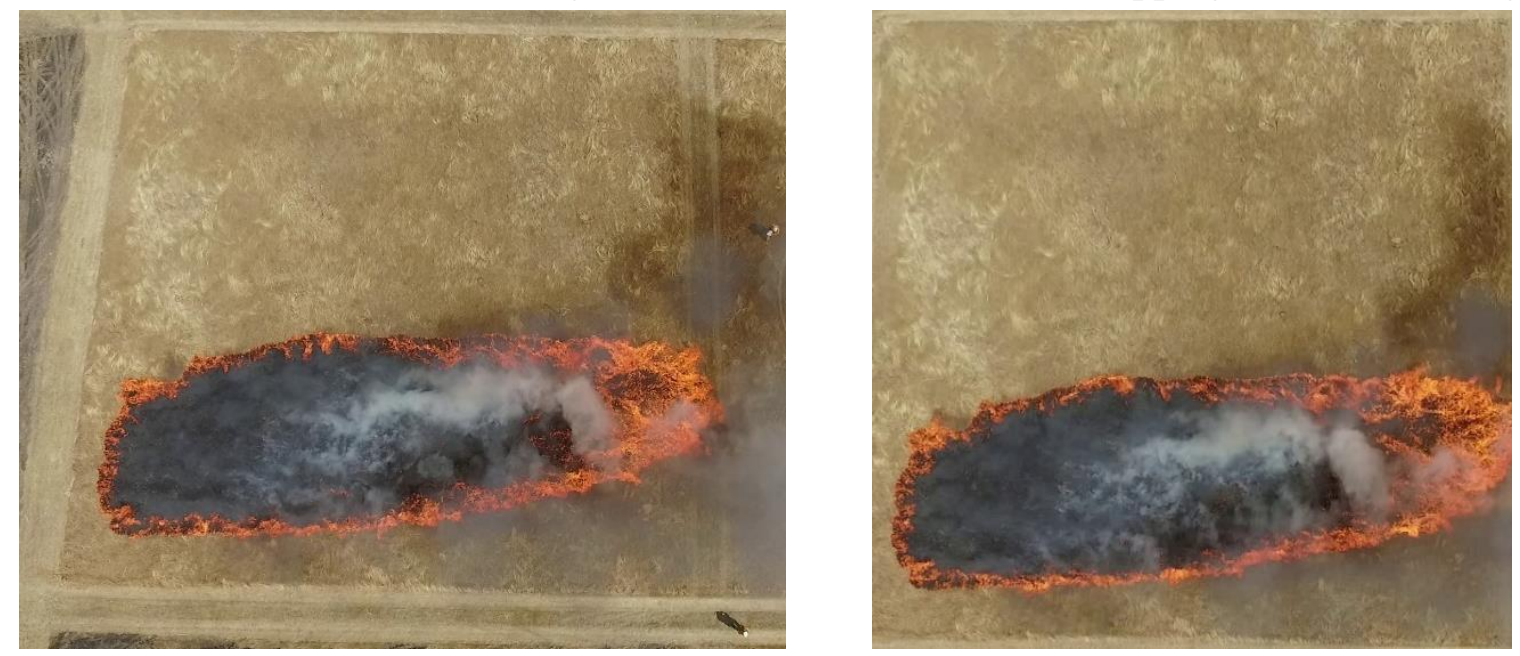

Figure 1 - (left) Example of a frame extracted from the raw RPA video of experimental fire B_S13. (right) The corrected, scaled, rectified and cropped image.

Figure illustrates an example of a series of raw images extracted from the video at 10 -second intervals showing the development of the fire and its spread across the experimental plot.

\footnotetext{
${ }^{1}$ http://imagej.nih.gov/il
} 

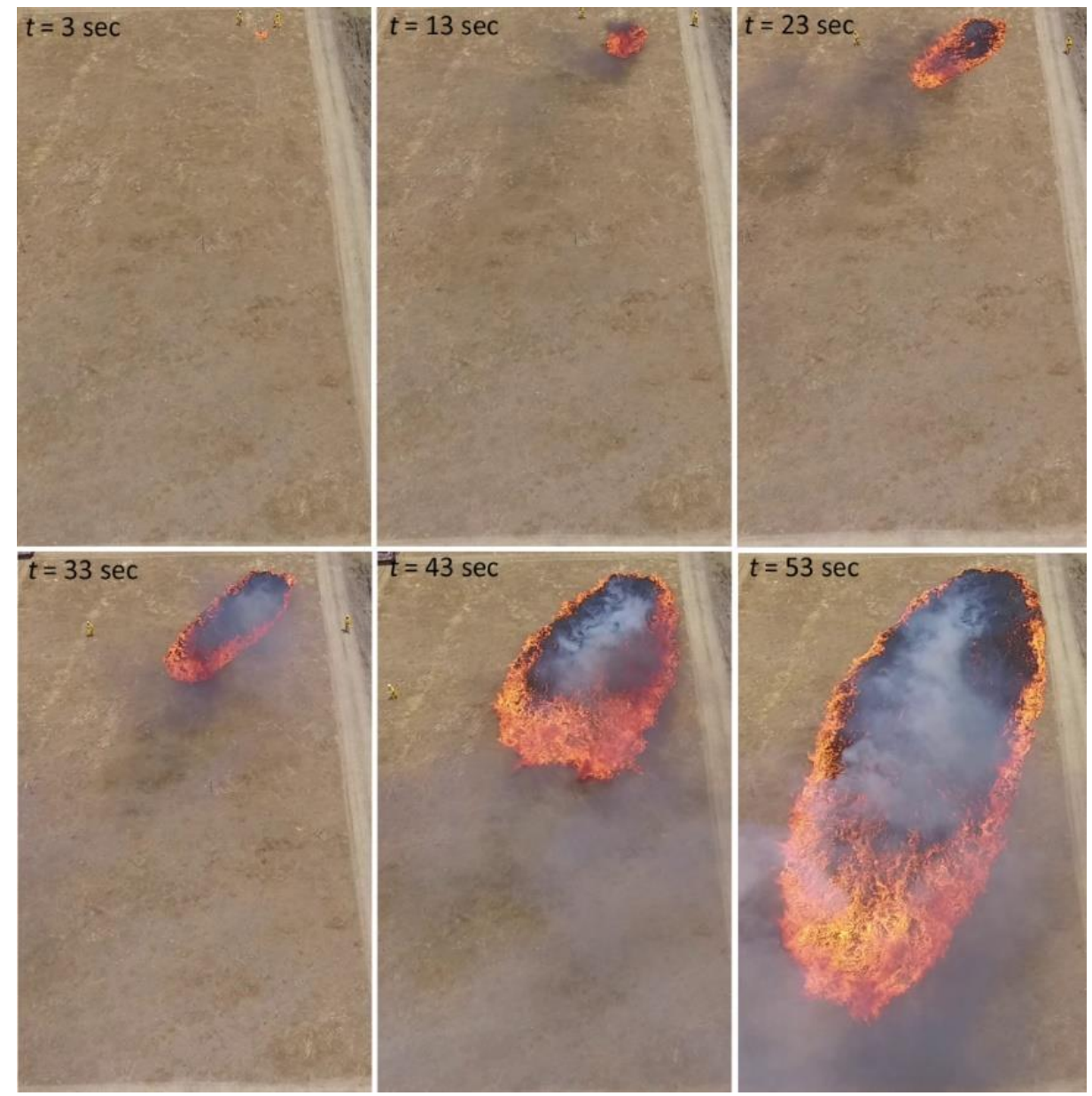

Figure 2 - Example of frames extracted from the raw RPA video of experimental fire $B \_$E28 each 10 seconds.

From the scaled and rectified imagery, the manually digitised fire perimeters enabled the construction of isochrone maps, two examples of which are shown below in Figure .
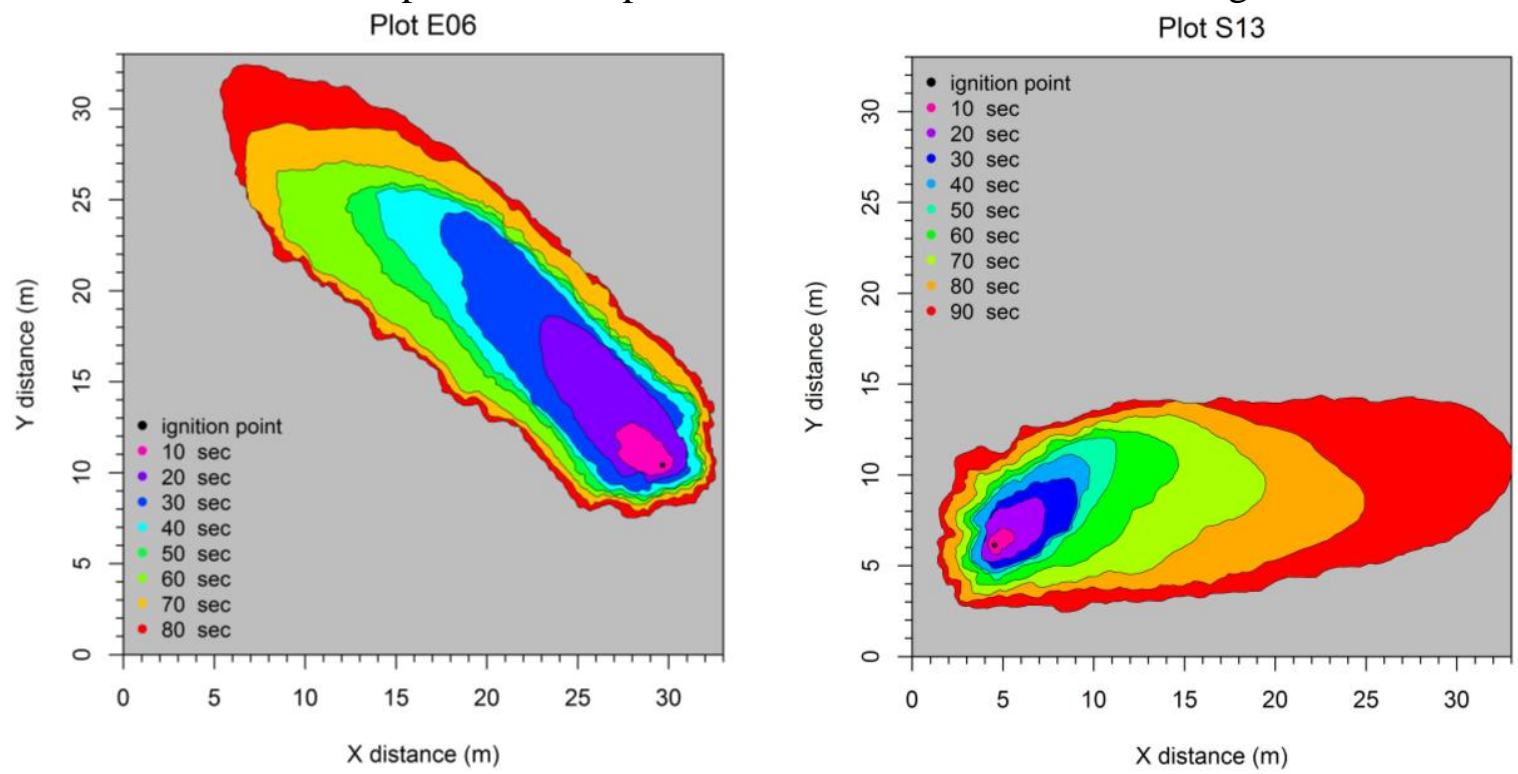

Figure 3 - Examples of two isochrones maps, one for B_E06 (left) and one for B_S13 (right). The interval and total number of isochrones depends on the speed of the fire and when it reached a plot boundary. 
Isochrone maps were then analysed for a variety of fire behaviour metrics. Figure summarises the rates of change in fire area, fire perimeter length, headfire width and length to breadth ratio over time since ignition for the subset of fires. Fire B_E28, burning on the largest experimental plot ( $0.2 \mathrm{ha})$ and under moderate fire weather conditions exhibited the greatest growth rates in terms of area increase, perimeter increase and headfire width. However fire B_E06 achieved the highest length to breadth ratio.
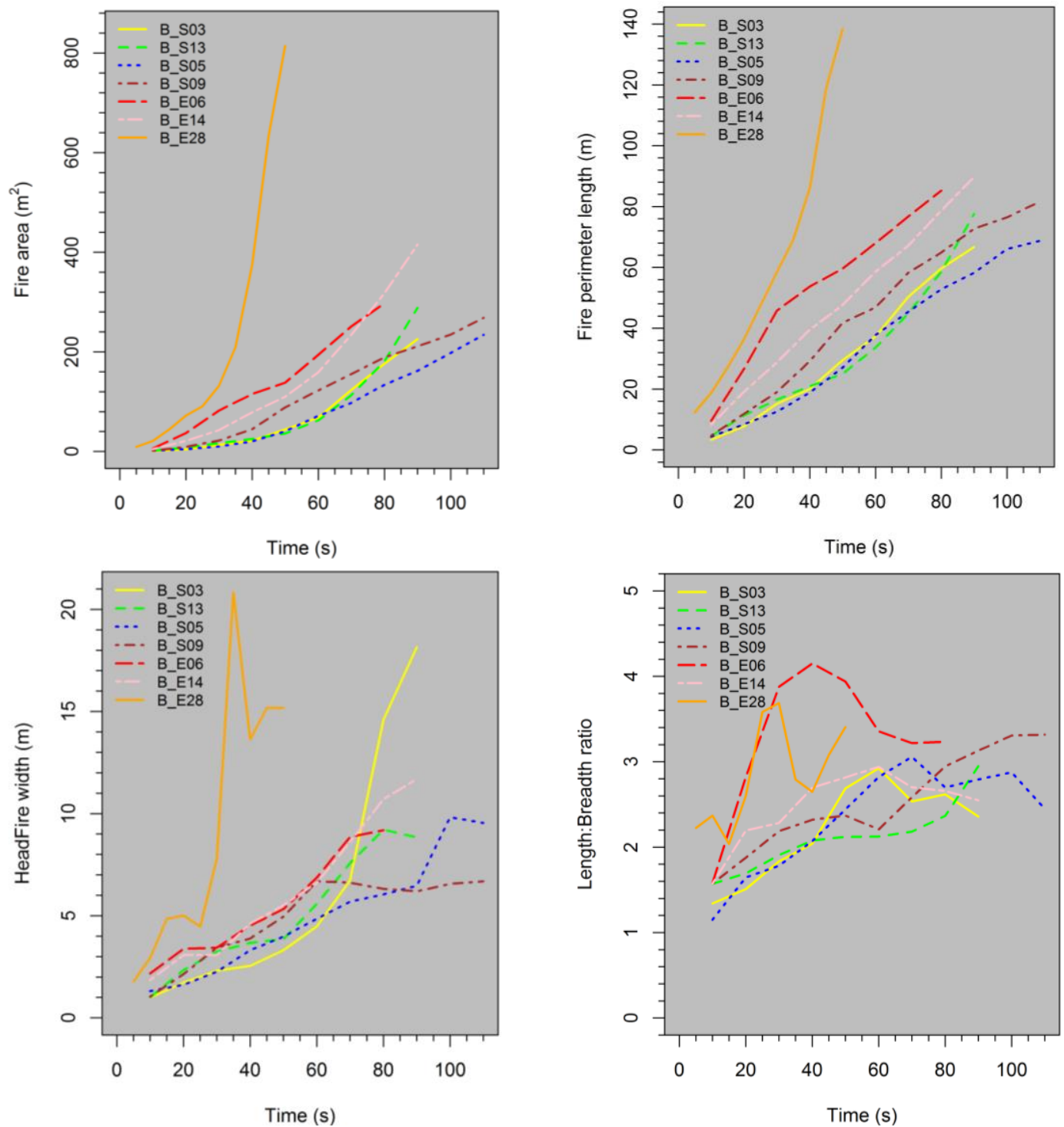

Figure 4 - Various fire behaviour and fire shape metrics for the point ignition fires. Clockwise from top left: fire area, fire perimeter length, length:breadth ratio and headfire width.

Interval spread distance and cumulative spread distance were estimated from the isochone maps as illustrated in Figure. The ignition point was determined from the location that the match was dropped and the direction of travel determined by maximum distance travelled in that interval. Graphs of interval rate of spread and interval acceleration, and cumulative rate of spread and cumulative acceleration is given in Figure and Figure, respectively. 


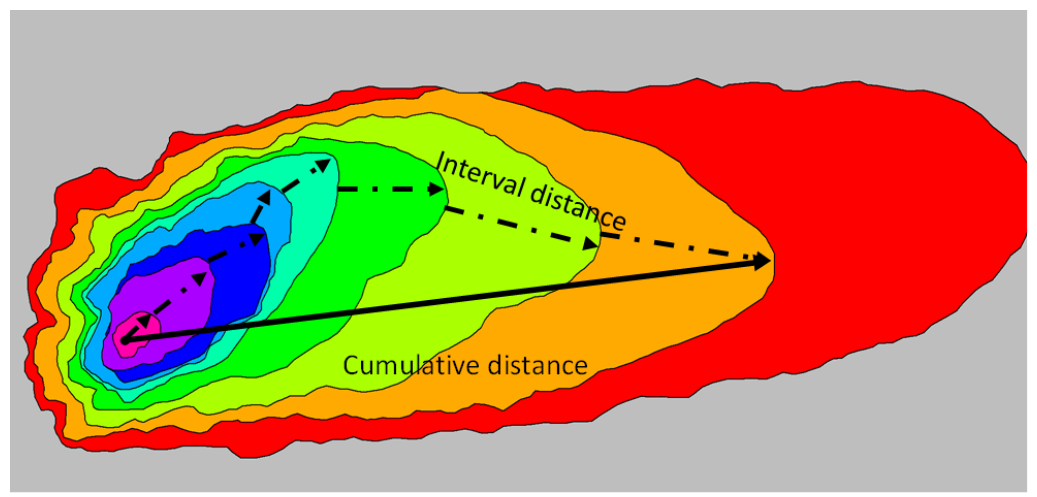

Figure 5 - Illustration of interval distance and cumulative distance in $B \_$E06. Cumulative distance is essentially the vectorial sum of the interval distances but in this case, because of the major shift in wind direction in the sixth interval, cumulative distance is much shorter than the scalar sum of the interval distances and thus will result in a lower overall rate of spread at this interval.
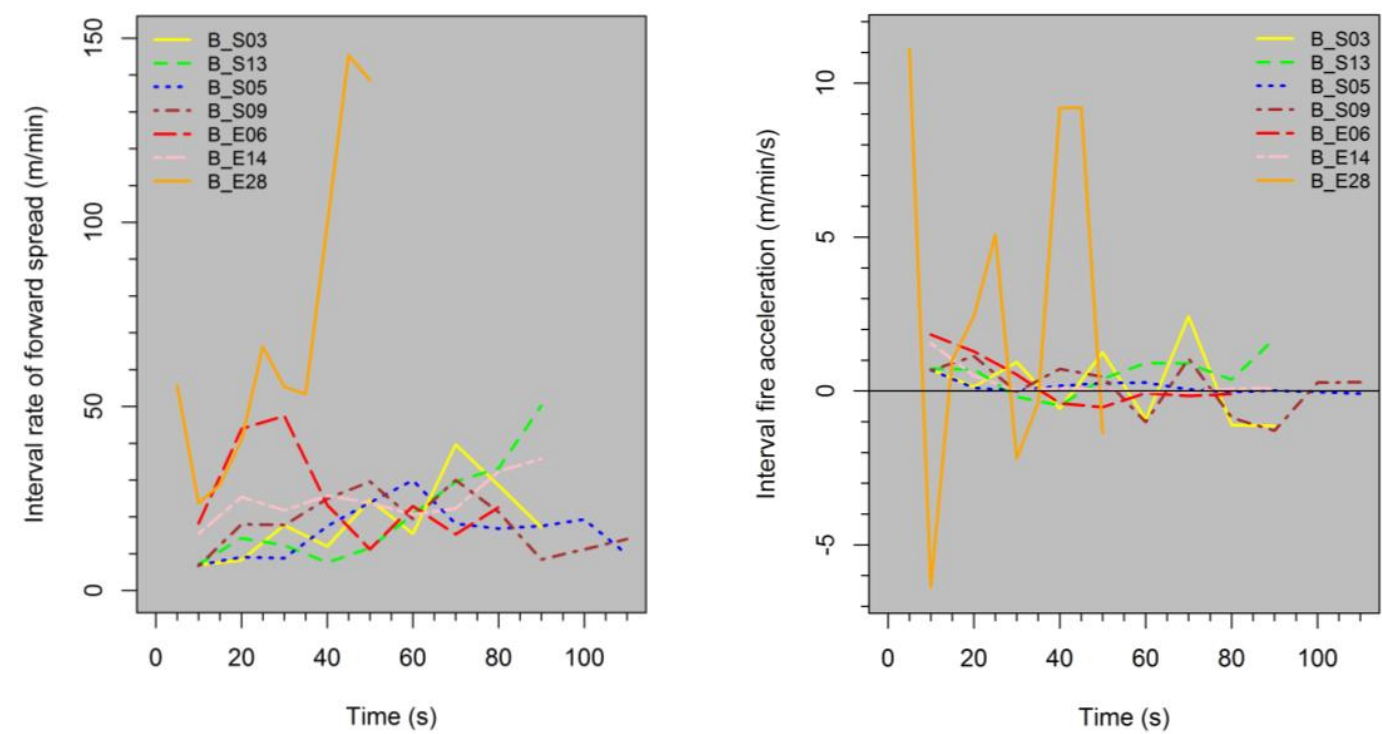

Figure 6 - Plot of interval rates of forward spread (left) and interval acceleration (right) for all fires.
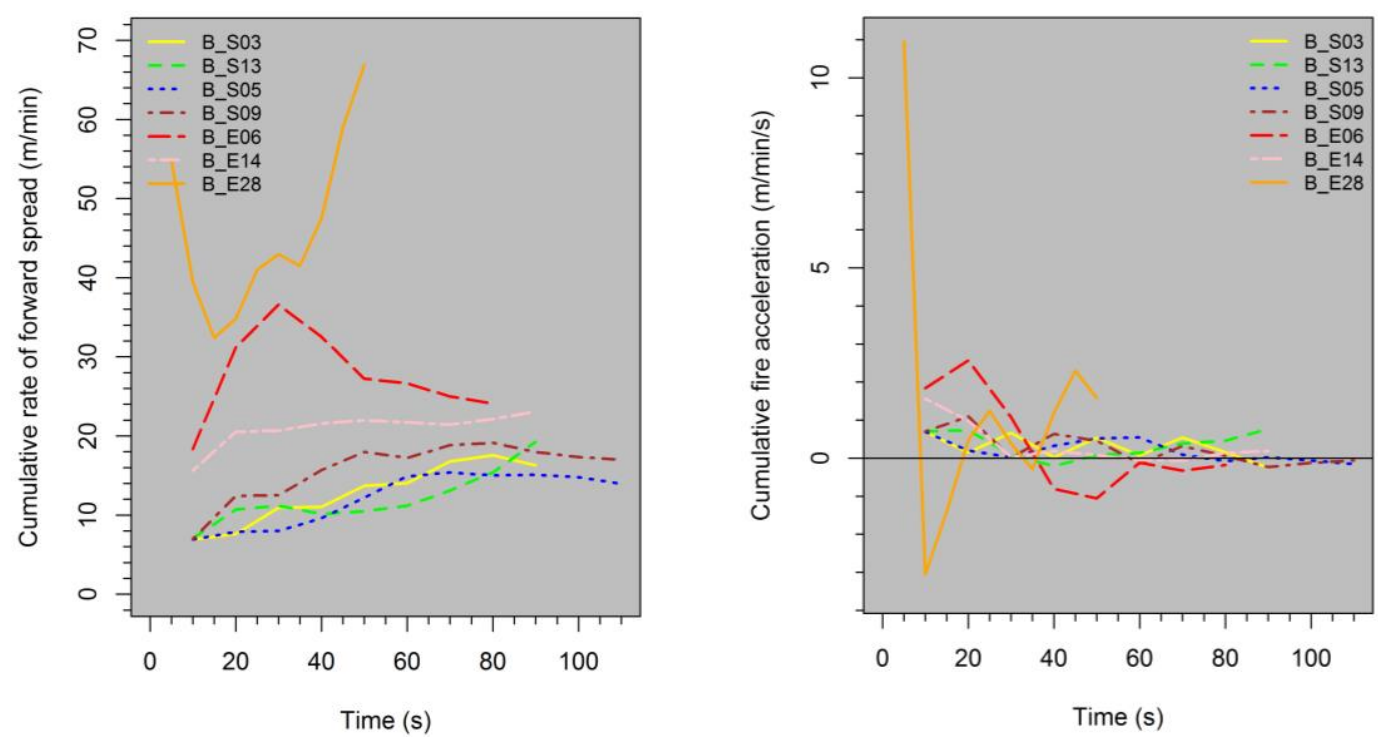

Figure 7 - Plot of cumulative rates of forward spread (left) and cumulative acceleration (right) for all fires. 


\section{Concluding remarks}

The development of a model to predict the build-up time to quasi-steady state is critical to understanding the time available to suppression crews for successful initial attack and for high fidelity landscape fire spread prediction. In the latter instance, build up time is not just applicable to new fire outbreaks or spotfires but also for break-aways from existing fire perimeters or control lines and fire spread through 'choke' points where fire width is constrained due to suppression action or changes in fuel condition.

This dataset provides a unique insight into fast developing fires, several of which very quickly attained or exceeded the predicted steady-state rate of spread for the prevailing conditions. The methodology of rectification and expert digitisation of the fire perimeters at regular but frequent intervals has produced isochrone maps of free-burning fires in the open at a previously unheard of temporal resolution.

It is envisaged that continued analysis of the dataset will enable the development of a model of grassland fire growth, particularly of wildfire outbreaks and possibly spotfires, that will benefit both fire spread simulation efforts as well as fire suppression planning and execution. This work will also be of benefit to research investigation the development of the two-dimensional shape of fires (e.g. Hilton et al 2016).

\section{Acknowledgements}

We are grateful to the Country Fire Authority of Victoria and the NSW Rural Fire Service for their support of this research. In particular we'd like to acknowledge the contributions of Alen Slijepcevic, Simon Heemstra, Laurence McCoy, Susan Kidnie, Rachel Bessell and Tim Wells for their contributions to this research. Our appreciation is also extended to numerous volunteer firefighters without whom we could not have conducted this experimental work.

\section{References}

Cheney NP, Gould JS and Catchpole WR (1993) The influence of fuel, weather and fire shape variables on fire-spread in grasslands. International Journal of Wildland Fire 3(1), 31-44.

Cheney NP and Gould JS (1995) Fire growth in grassland fuels. International Journal of Wildland Fire 5(4), 237-247.

Cleary PW, Thomas D, Bolger M, Hetherton L, Rucinski C and Watkins D (2015) Using Workspace to automate workflow processes for modelling and simulation in engineering. In: Weber T, McPhee MJ, Anderssen RS (eds), MODSIM2015, 21 st International Congress on Modelling and Simulation, December 2015, pp. 669-675.

Hilton JE, Miller C and Sullivan AL (2016) A power series formulation for two-dimensional wildfire shapes. International Journal of Wildland Fire 25(9), 970-979.

Luke RH and McArthur AG (1978) Bushfires in Australia. Australian Government Publishing Service, Canberra ACT. 359 pp.

McAlpine R and Wakimoto R (1991) The acceleration of fire from point source to equilibrium spread. Forest Science 37(5), 1314-1337.

McArthur AG (1966) Weather and Grassland Fire Behaviour. Forestry and Timber Bureau Leaflet 100, Commonwealth Department of National Development. Canberra, 23 pp.

Sullivan AL, Cruz MG, Gould JS, Ellis PF, Plucinski MP, Hurley R and Koul V (2013) Fire Development, Transitions and Suppression: Final Report. CSIRO Ecosystem Sciences and CSIRO Climate Adaptation Flagship Client Report EP1312986, Canberra, ACT. 197 pp. 